Knowledge in the Blood 



\title{
Knowledge in the Blood \\ Confronting Race \\ and the Apartheid Past
}

\author{
Jonathan D. Jansen
}

Stanford University Press

Stanford, California 
Stanford University Press

Stanford, California

(C)2009 by the Board of Trustees of the Leland Stanford Junior University. All rights reserved.

The poem on p. v is reprinted from Macdara Woods, Knowledge in the Blood: New and Selected Poems (Dublin, Ireland: Dedalus Press, 2007), 101. Used with permission of the Dedalus Press, www.dedaluspress.com.

No part of this book may be reproduced or transmitted in any form or by any means, electronic or mechanical, including photocopying and recording, or in any information storage or retrieval system without the prior written permission of Stanford University Press.

Printed in the United States of America on acid-free, archival-quality paper

Library of Congress Cataloging-in-Publication Data

Jansen, Jonathan D.

Knowledge in the blood : confronting race and the apartheid past / Jonathan D. Jansen. p. cm.

Includes bibliographical references and index.

ISBN 978-0-8047-6194-9 (cloth : alk. paper)--ISBN 978-0-8047-6195-6 (pbk. : alk. paper)

1. University of Pretoria--Administration. 2. College integration--South Africa. 3.

Educational change--South Africa. 4. Afrikaner students--South Africa--Attitudes. 5.

College students, White--South Africa--Attitudes. 6. Racism in higher education--South

Africa. 7. Post-apartheid era--South Africa. 8. South Africa--Race relations. I. Title.

LG471.P7J36 2009

$378.68^{\prime} 227--\mathrm{dc} 22$

2008054140

Typeset by Bruce Lundquist in 11/15 Bell MT 


\section{Time and the Ice-Fish}

This is it now the lighthouse

any further we can not

than the sea-wall's end

like the others we must drop back

This week-end-in a day or less they are turning the clocks back and we will hear the cogs mesh and the minutes beginning to tick

Because there is no respite from the knowledge in the blood this is a fearful country this bleak landscape of the ice-fish 
